\title{
Examining the relationship between service quality and customer satisfaction in the public service. The case of Botswana
}

\author{
PHETOGO MOSIMANEGAPE \\ Botswana Open University, B2 76: \$1 \$ \\ OLUMIDE JAIYEOBA \\ Botho University, B2 76: \$1 \$ \\ CHUX GERVASE IWU \\ Cape Peninsula University of Technology, S2 8 7+ [\$ ) 5, \&\$ \\ CHENESO CHEKULA-MAHAMA \\ Tonata Sub Regional Education, Ministry of Basic Education, B2 76: \$1 \$
}

\begin{abstract}
Sustaining public confidence in any government is also a function of the consistency in the delivery of public goods and services. For several years, customers across public organizations have complained about the quality of services delivered to them. It is therefore important for public organizations to regularly evaluate service quality in order to better understand how best to satisfy customers. This study investigated the extent to which dimensions of service quality influence customer satisfaction in the Tonota Sub Region. With the aid of a questionnaire, data were collected from 135 respondents located at 27 basic education sites (secondary and primary schools) in the Tonota Sub Region. Descriptive and inferential statistics were used for data analysis. The findings reveal that service quality dimensions of tangibility, empathy, assurance, and responsiveness impact customer satisfaction positively. This study recommends amongst others, training of employees on managing customer complaints, records management and increasing service reliability to improve service quality. The outcome of this study will guide the formulation of customer satisfaction strategy and policy aligned with service standards to drive service quality delivery. Future research is recommended on perceptions of teachers and other members of the public regarding the extent to which service quality impacts customer satisfaction so as to comprehensively discern public service quality dimensions. An understanding of customer satisfaction within the public service will likely kindle better relations between the public and government thereby improving public trust in government programs. Managers are also likely to tap into this to further levels of job satisfaction for public sector employees.
\end{abstract}

Key-Words: - Customer satisfaction; Quality service delivery, Service quality dimensions, Public Service, Tonota-Botswana; SERVQUAL

Received: December 28, 2019. Revised: May 14, 2020. Re-revised: May 29, 2020. Accepted: June 1, 2020. Published: June 4, 2020.

\section{Introduction}

According to Jenkins [1], sustainability refers to "a capacity to maintain some entity, outcome, or process over time". This description suggests that "to sustain something, the resources that it depends on must be available at all times for it to continue to exist" [2]. Sustainable public service can then be argued to mean a service that is harvested over a long period and offers the capacity to delight. Therefore, to measure public service quality requires a determination of the extent to which customers and or users of public service are satisfied.

Customer satisfaction has globally become a strategic initiative for organizations to achieve their objectives. Customer satisfaction is primarily measured to assess how well an organization meets the needs of its customers and what should be done better [3; 4]. According to Paul, Mittal and Srivastav [5] and Kant and Jaiswal [6], the perceived performance of a product is compared to the expected standards of that performance. This implies that customer satisfaction is more of an outcome of comparison between the level of service provision or product performance and the set organizational standards of service. Basically, the customer undertakes a comparison of a product or service before and after a purchase $[5 ; 6 ; 7]$. Therefore, a customer is said to be satisfied when (1) the purchasing experience is delightful and (2) the product or service meets the reasons for its purchase $[5 ; 6]$.

Poor service delivery is widely reported within the public sector. For example, several 
studies $[8 ; 9 ; 10]$ have reported excessive complaints by customers seeking to access public services. This is despite the decentralization of functions to districts by government as a way to

Table 1: Papers Published on Service Quality and Customer Satisfaction in Botswana

1. Effects of Service Quality on Customer Satisfaction on Botswana's Mobile Telecommunications Industry by G.B Selelo and K.R Lekobane: Archives of Business Research Vol. 5 No. 3 (2017)

2. A service quality Framework for the Botswana Hospitality Sector: G.M Musikavanhu (Unpublished Dissertation $\mathrm{PhD}$ : Tourism Management, North-West University, Potchesfstroom Campus.

3. A netrographic Analysis of Online Reviews of Restaurant Service in Botswana by D. Chatibura and M. Siya, Botswana Journal of Business Vol. 11 No. 1 (2018).

4. Customer Satisfaction in the Airline Industry: The role of service quality, Brand image and customer value, M.O Madikwe: Unpublished MBA Dissertation.

5. E-service usage and satisfaction in Botswana by O.O Jaiyeoba, T.T, Chimbise and M. Roberts Lombard: African Journal of Economic and Management Studies (2018).

6. BOCRA customer satisfaction survey Draft Final Report (2015) by Botswana Institute for Development Policy Analysis (BIDPA).

7. Customers perception of Service Quality and its impact on reputation in the Hospitality industry by T. Mmutle and L. Shonhe, Vol. 6 No. 3 (2017): African Journal of Hospitality, Tourism and Leisure.

8. The Gaps Model of Service Quality and Higher Education Delivery in Botswana: An internal Customer Perspective by Ushe Makambe Vol. 5 Issue 3 (2016) International Review of Management and Business Research: Gaps Model of Service quality is different from the parsimonious model adopted for this empirical study.

9. Perceptions of quality service at the University of Botswana Library: What Nova says: A.P Thapisa and V. Gamini, Journal of Library Management (1999). Vol. 20, No. 7 pp: 373-383

10. Using the Servqual Model to Evaluate the impact of Public service reforms in the Provision of Primary Health Care in Botswana: J. Pansiri and R.N Mmereki (2010): pp: 219-234. bring services closer to the people in an attempt to facilitate service delivery. Owing to frequent customer complaints regarding poor quality service within government parastatals, management of public sector services has come under severe scrutiny [8]. Governments are therefore under pressure to provide the needed services to their citizens on time $[9 ; 11]$. Essentially, service delivery remains an important obligation of any government to its citizens, which heightens the need for reform programs and processes aimed at bringing about access to quality public goods and services [11].

Several studies have established the nomological web between customer satisfaction and service quality metrics: reliability, responsiveness, assurance, empathy and tangibility. For instance, a study by Pizam et al. [3] on customer satisfaction in hospitality enterprises in the United States of America established that the aforementioned service quality metrics positively influenced customer satisfaction. Ali, Dey and Filieri [12] examined service quality and customer satisfaction of air travel in Pakistan and found that all service quality dimensions (responsiveness, reliability, empathy and assurance) had strong influence on customer satisfaction. Furthermore, Wu's [13] research on how some dimensions of service quality impacted gaming establishments in China found that service quality substantially influenced perceived value and corporate image. $\mathrm{Wu}[13]$ also found that perceived value and corporate image were determining factors of customer satisfaction.

As far as we know, only very few service quality-oriented studies have taken place in Botswana. Therefore, this study adds to the literature on service quality as it affects Botswana. Besides this, and as Table 1 depicts, there is no study which has investigated the nomological web between service quality and customer satisfaction in Botswana's public sector specifically the education sector.

The value of this study is consistent with the national human resource development value proposition as indicated in the National Human Resource Development Strategy, 2009-2022 [14]: Realising Our Potentials: Republic of Botswana: Ministry of Education and Skills Development.

This strategic document is centred around national development, but more importantly aligned to issues of education and training, citizen empowerment, and research and innovation that facilitates the development of the average citizen of Botswana. The citizens of Botswana are the greatest asset and the guarantors of the nation's long term 
prosperity as indicated in NHRDS, 2009-2022 [14]. Based on the aforementioned, service quality and customer satisfaction lend credence to access, quality, relevance, excellence and developing a high performance culture as enshrined in the NHRDS 2019 Annual Report. As stated in the annual report, a comprehensive and quality secondary education system provides various opportunities to graduates to pursue several walks of life. To this end, an understanding of the quality of services offered by education authorities will go a long way in addressing issues that not only hamper the delivery of teaching and learning, but also facilitates the elevation of Botswana in global competitiveness. Currently, Botswana ranks 91 out of the 140 countries in the global competitiveness report published by the World Economic Forum [15].

Most of the studies pertaining to service quality have taken place in the cities of Gaborone and Francistown. Tonota Sub district is a burgeoning region located in the Central District of Botswana and has recently become a beehive of economic activity following in the heels of Gaborone and Francistown, which are renowned for their commercial status.

\section{Literature review}

\subsection{The state of public service delivery in Botswana}

In Botswana's government departments, service delivery is badly characterized by long queues, arduous paper work, bureaucracy, cramped spaces and a lot of frustration [9]. According to Kealesitse et al. [8], Ramakele and Koloi-Keaikitse [10], and Hope [16], the public sector in Botswana is known for not sufficiently responding to the needs of its customers.

There are several examples in Botswana of low levels of customer satisfaction in terms of the delivery or implementation of public service programs or projects across the ministries $[17 ; 18$; 19]. According to Botlhale [18], examples of projects which were poorly delivered include the National Stadium in Gaborone, Sir Seretse Khama International Airport in Gaborone, Francistown Stadium in Francistown, Morupule B Power Plant in Palapye and the Glass Plant in Palapye. Other examples of poor delivery include the under-spent development budget of about $17.3 \%$ between 2012/2013 and 2013/2014 years; cost overruns, poor quality projects; and the water crisis $[18 ; 17]$.

Similarly, Jaiyeoba, Chimbise, Makanyeza and Iwu [20] reported that the health insurance sector in Botswana is faced with problems of inexpediency and customer discontent. The authors lamented that these could be counterproductive for businesses such as the Associated Funds Administrators (AFA), Botswana Public Officers Medical Aid Scheme (BPOMAS) and PULA Medical Aid (PULA). As far as the current study is concerned, the Tonota Sub Region Education Office is not exonerated from the poor service delivery record of Botswana, and hence the need for this study. According to Yuen and Thai [21] and Shin, Thai and Yuen [22], the lack of trust and commitment in the maritime logistics industry, was identified as one of the key factors preventing firms from collaborating or obtaining full benefits of service industry in an era of global competitiveness in the service industry.

Recently in April 2018, the Botswana Daily News newspaper reported that the President, Mr. Mokgweetsi Masisi was concerned about poor customer service delivery in Botswana, particularly in the public sector. Swiftly, he took his entire Cabinet Ministers for a retreat to share his vision and strategy on improving public service delivery in Batswana [23]. Notwithstanding some chequered reporting of service delivery issues within the public sector of Botswana government, the government introduced initiatives such as the National Productivity Program, Work Improvement Teams Strategy (WITS), decentralization and a Performance Management System (PMS) to address concerns over public service delivery.

Despite the above initiatives, reports of customer dissatisfaction continue to be recorded in Botswana as noted by Botlhale [18]; Jaiyeoba et al. [20] and NDP 11 [19]. However, interestingly, some studies equally found a positive influence of service quality dimensions on satisfaction. For instance, Kealesitse et al. [8] found that improved performance and responsiveness shaped customer perception positively. Similarly, Jaiyeoba et al. [20] found that responsiveness had a positive impact on customer satisfaction for services at the Botswana Public Officers Medical Aid Scheme and Pula Medical Aid.

Numerous studies on customer satisfaction with regard to public service in Botswana and elsewhere have focused on the final customers [24]. Few studies have focused on internal customer satisfaction delivery $[25 ; 26 ; 20]$ with particular reference to school managers and supervisory departments or units. For this reason, this study focused on customer satisfaction and service quality 
within the Tonota Sub Region's Education Office in Botswana.

\section{Theoretical Foundations}

\subsection{Customer satisfaction}

There are numerous descriptions ascribed to customer satisfaction. Bellingkrodt and Wallenburg [27] define customer satisfaction as the extent to which customers of an organization repeatedly identify with an organization's products and services. Thus, if customers continually perceive a product or service positively, Bellingkrodt and Wallenburg [27] argue that this mental state can nurture customer loyalty.

Examining whether customers of a public utility in Malawi are satisfied or not led Chodzaza and Gombachika [28] to define customer satisfaction as a reflection of the pleasure level of a consumer. Customer satisfaction should rather be seen as the overall attainment of a customer's expectation. This is the contention of Oludele et al. [24] while researching the degree of citizen satisfaction with regard to public service in South Africa. In other words, to understand customer satisfaction requires measuring the extent to which a customer's expectations have been met. This description is consistent with the definition offered by Jaiyeoba, Chimbise and Roberts-Lombard [29] in a study of E-service usage and satisfaction in Botswana where they referred customer satisfaction as the mindset of customers regarding positive expectations of a product or service. They further argued that providing high-quality customer care, including constant communication and good employee conduct have the potential to keep a customer satisfied.

Based on the aforementioned, this study lends credence to the theory of reasoned action expanded by Fishbein and Ajzen [30]. According to this theory, the attitude toward behavior and subjective norms make up one's behavioral intention and subsequent display of behavior. Interestingly, the subjective norm represents one's set of beliefs while the normative beliefs represent the probability that an intention and or its subsequent display is approved as argued by Meskaran, Ismail, and Shanmugam [31]. As far back as 1975, Fishbein and Ajzen argued that whatever behavior is displayed is dependent on one's instincts, which often are made up of four distinct elements: the action, the target at which the action is directed, the context in which the action is performed and the time at which it is performed.
Tsoukatos and Mastrojianni [32], thus suggest that continuous evaluation of the dimensions of SERVQUAL is critical in order to fulfil customers' aspirations. Hamzah, Lee and Moghavvemi [33] context-specific understanding of SERVQUAL remains a key issue that requires further investigation, thus the need for the development of service quality metrics dimensionality for public sector in Botswana. This study thus seeks to adopt Lee and Moghavvemi's [34] study which identified dimensions based on the most cited and most applicable SERVQUAL dimensions namely tangibles, empathy, reliability and convenience.

Even though the mental state associated with satisfaction starts with what the customer expects, much of its consideration is retrospective. The views of Daniel and Nicholas [35] are also consistent with this account in that if a customer notes dissatisfaction with a product or service, it is based on the customer's analysis of his or her expectations before and the experience on encountering the product or service. This suggests that the customer would have evaluated the overall experience of encountering the product or service over a period. Jamali [36] agrees with this ex post facto illustration of customer satisfaction. Her view is that post-consumption evaluation contains both cognitive and affective elements and goes further to distinguish for example between "satisfaction as contentment or happiness", "satisfaction as pleasure or enjoyment", and "satisfaction as relief or assistance" implying that customers have different motives for different levels of satisfaction.

Customer satisfaction may further be viewed as a psychological attainment derived from product or service use; or a mental state whereby the customer undertakes a comparison of a product or service before and after a purchase [5]. It can be concluded that with regard to public service, customer satisfaction is concerned with level of service delivery expectations before receiving service and perceptions after getting the service. It could be argued therefore that in public service, customers would be satisfied when they are happy with the service they receive without experiencing delays or any difficulty.

\subsection{Service quality}

Several researchers such as Paul et al. [5] describe service quality as the difference between what a customer expected of a service prior to encountering it and his or her perceptions of the service after it is received. Specifically, service quality is determined on the basis of customers' assessment of the service that they receive [6]. 
Service quality metrics or attributes are used to measure the orientation of services as perceived by the customer. Service quality perspectives have been described as the elements or factors or parameters widely accepted and adopted to measure service quality in the SERVQUAL instrument. These parameters are adopted to infer service quality metrics or gauge levels of customer satisfaction in any organization [37].

\subsection{The SERVQUAL model}

The SERVQUAL model is commonly adopted to understand customer satisfaction. It is especially adopted to measure gaps in service orientation. The SERVQUAL model postulated by Parasuraman et al. [38] over the years has been extensively applied by many authors $[37 ; 5]$.

According to Hui and Zheng [7], in terms of the SERVQUAL model, customers evaluate service quality dimensions by comparing service outcome with actual performance. They indicate that service dimension is a function of the perspectives between expectations and perceptions. Therefore, Alzaydi et al. [37] define service quality as the difference between perception $(\mathrm{P})$ and expectation (E). Jaiyeoba et al. [20] and Jaiyeoba et al. [29], in a study of e-service usage metrics and satisfaction in Botswana contended that SERVQUAL is a leading model used to evaluate service quality and to assess customer satisfaction.

The SERVQUAL instrument has 22 scale items used to evaluate service quality dimensions namely tangibility, reliability, responsiveness, assurance and empathy. Each sub construct measures expectations and perceptions [37]. With minor modifications, Alzaydi et al. [37], Chodzaza and Gombachika [28] and Wisniewki [40] argue that the SERVQUAL can be adapted in any firm. By doing so, service quality gaps are identified which managers benefit from while investigating how best to target performance metrics. In fact, Alzaydi et al. [37], Chodzaza and Gombachika [28] and Wisniewki [40] are also of the view that the identification of these gaps including pinpointing the performance metrics lead to better focus on performance outcomes.

In addition, positive gap in service or exceeded expectations indicate that there are "over-supplied" features of the service and re-deployment of resources. This is relevant for the public sector as its resources are increasingly under pressure [37].

Furthermore, a breakdown of five service quality dimensions into separate statements allows a firm to focus on particular problem areas thereby improving service delivery. For example, in the UK and Scotland, the SERVQUAL model has been used in different sectors including catering service, public libraries, housing, grounds maintenance and leisure services [40]. This is an indication that SERVQUAL model can be applied across different public sector services to assess the customer satisfaction.

Based on the aforementioned, it is clear that the SERVQUAL model can be utilized to investigate service quality and service performance in either the public or private sector.

\subsection{Theoretical model development}

This section describes customer satisfaction and explores its importance and relationship to service delivery in Botswana. A conceptual framework is derived based on meta analytical review of extant literature.

\subsubsection{Reliability and customer satisfaction}

Reliability has been defined as the firm's capability to provide services accurately, and efficiently [37].

In a study using the SERVQUAL instrument to evaluate customer satisfaction metrics on public sector services, Wisniewki [40] found that reliability had positive gap scores meaning that what the customers expected were surpassed by the public library. For example, the library had reliable equipment such as photocopiers, internet, and processes that helped it to attain the needs of the library users. Similarly, in India, Paul et al. [5] found that in public and private sector banks, reliability positively influenced customer satisfaction. The study also found that trust and dependable services influenced the users' evaluation of service quality in public and private sector banks. The reliable uses of the internet, ATMs and operational times were cited as examples considered by customers.

In another study, Andrews and Turner [41] found that reliability had a substantial affirmative influence on customer satisfaction in the UK. The findings showed that the employee's commitment to provide dependable quality service positively influenced customer satisfaction. A similar study by Brysland and Curry [42] found similar results in the UK.

Other studies that found a significantly positive influence of reliability on customer satisfaction include: Jamali [36] in Lebanon and Kaura [46] in India. In Botswana, Thapisa and Gamini [43] found a positive relationship between user-friendliness of library services at the University of Botswana and the reliability of available information. In another study in Botswana, Jaiyeoba 
et al. [20] found that efficiency and system availability had a positive impact on the customers also established a positive relationship to the perceived value of the health insurance. We therefore hypothesize that:

H1: Reliability measure is significantly and positively related to customer satisfaction.

\subsubsection{Responsiveness and customer satisfaction}

Responsiveness has been defined as the desire to help customers and the ability to provide timely services [37]. Andrews and Turner [41], in a study on customer experience in service delivery in the UK public sector established that the quality of employee performance, marked by responsiveness, competence, and promptness, influenced customer satisfaction. Silvestri et al. [44], in a study on service quality and customer satisfaction in thermal tourism, found that the employee's desire to help customers, the promptness of services, and the capacity to provide individualized attention to clients provided more customer satisfaction.

Other studies that found a positive impact of promptness and responsiveness on customer service respectively include those of Bitterncourt et al. [45], Kant and Jaiswal [6] in India; Kaura [46] and Jamali [36] in Lebanon. Similarly, Frimpong and Wilson [47], in a study of the relative importance of satisfaction dimensions on service performance in Ghana, established that all the dimensions predicted customer satisfaction. In Namibia, Whyte and Bytheway [48] found that responsiveness, courtesy and competence had a positive impact on customer satisfaction on service orientation. They argued that responsiveness, competence and courtesy of staff reflected the culture of the organization towards service quality performance.

Finally, in Botswana, different studies have similarly found a positive influence of the service quality metrics on customer satisfaction. For example, Kealesitse et al. [8], in a study on customer-focused public sector reward schemes in Botswana, found that customer orientation sets the platform for enhancing customer satisfaction and competitiveness. They also suggested that customer orientation had a positive influence on employees' performance and motivation within the public sector. The study found that responsiveness reduced queues and hassles when customers sought services. Jaiyeoba et al. [20] also found that responsiveness had a positive effect on customer satisfaction for websites services and value of the e-mail services. This study was conducted on the Botswana Public Officers Medical Aid Scheme and Pula Medical
Aid. The study further found that responsiveness contributed to efficiency and fulfilment in addressing the health insurance schemes members' complaints. Based on the aforementioned, we further hypothesize that:

$\mathrm{H} 2$ : Responsiveness measure is significantly and positively related to customer satisfaction.

\subsubsection{Assurance and customer satisfaction}

Assurance signifies employees' knowhow, competence, courtesy, safety and capability to inspire trust and establish confidence in customers [37].

The empirical findings in a study by Kant and Jaiswal [6] reveal that assurance was a significant antecedent of customer satisfaction in public sector banks in India. Similarly, Kaura [46], in a study on banks in India, found that assurance metric had a positive influence on customer satisfaction. Brysland and Curry [42], in a study investigating service improvement in public services in the UK, found that the assurance dimension, which received the highest expectations score from the education and housing departments, had a significant influence on customer satisfaction.

Other dimensions with a positive impact on customer satisfaction include: customer focus; abilities, trustworthiness and assurance; assurance and responsiveness; professional service, efficiency, courtesy; and security. Jaiyeoba et al. [20] in a study on health care insurance in Botswana found that assurance positively impacted customer satisfaction with the use of websites and emails. Also in Botswana, Thapisa and Gamini [43] found that assurance had a positive relationship with userfriendliness of library services at the University of Botswana. Jain [26] also reported that employee commitment and customer focus (implying assurance) influence customers in a study on Botswana National Library Services. We thus hypothesize that:

H3: Assurance measure is significantly and positively related to customer satisfaction.

\subsubsection{Empathy and customer satisfaction}

Empathy indicates the provision of caring, individualized attention to customers. It covers access, effective communications, market driven customer needs, and friendliness [37].

Kaura [46] and Kant and Jaiswal [6] conducted different studies that found that politeness, personalized attention and empathy of the employees towards customers had a positive 
influence on their satisfaction in the Indian public and private sector banks. Employee courtesy, trust, social bonds (empathy), expertise, efficiency, and image were found to positively impact customer satisfaction on service delivery by Paul et al. [5] in Indian public banks as well.

In another study investigating customer experience in the public sector, Andrews and Turner [41] found that the quality of employee performance and empathy generated guests' emotional experience that had positive effect on customer satisfaction. In addition, Silvestri et al. [44] found that the employees' ability to perform accurately, dependably - desire to help customers, provision of timely service and personalized attention or empathy - appeared to give more satisfaction to users in thermal tourism. Biscaia et al. [49] in Portugal conducted a study in retail sports stores and found a positive effect of image and empathy dimensions on customer satisfaction with regard to service orientation.

In Nigeria, Izogo and Ogba [25] found that positive relationship exists between the empathy dimension of service quality and customer satisfaction in the automobile sector. The study found that as the empathy perspective increases, customer satisfaction level will also increase. On the other hand, Russell and Bvuma [50], in a study of service delivery and public sector reform found that initiatives like Batho Pele (putting people first implying empathy) positively influenced customer satisfaction. Finally, in Botswana, Jaiyeoba et al. [20] found that system availability, efficiency, fulfilment, empathy and contact had a significant and positive influence on customer satisfaction for websites and e-mail services for the health insurance sector. We thus hypothesize that:

H4: Empathy measure is significantly and positively related to customer satisfaction.

\subsubsection{Tangibility and customer satisfaction}

Tangibility signifies the physical facilities, equipment, appearance of personnel, corporate image, cleanliness and intangible elements [37].

Several studies have confirmed a positive effect of tangibility on customer satisfaction in the Indian public sector banks. Silvestri et al. [44] in a study of service quality and customer satisfaction in thermal tourism found that appearance, cleanliness, comfort, safety and tangibility of the resort spa and thermal pool gave more satisfaction to the users. In another study, tangibility and security were found by Whyte and Bytheway [48] to have a positive effect on customer satisfaction in Namibia. The study found that in terms of tangibility, banks are perceived to perform excellently.

However, Kaura [46] found that with the exception of tangibility, other dimensions of service metrics had a positive influence on customer satisfaction in Indian banking sector. Similarly, in a study on customer experience on service delivery in the UK public sector, Andrews and Turner [41] found that tangible elements have less influence on customer satisfaction. This might suggest less attractive service environment and equipment which shrinks performance.

Finally, in Nigeria, Izogo and Ogba [25], in a study of services orientation metrics and customer satisfaction on automobile repair sector, found a positive relationship between the tangibility metrics of service perspectives and customer satisfaction and loyalty. The authors argue that the perceived level of tangibility lend credence to customer satisfaction and loyalty. We thus hypothesize that:

H5: Tangibility measure is significantly and positively related to customer satisfaction.

Figure 1: Conceptual model of Customer satisfaction

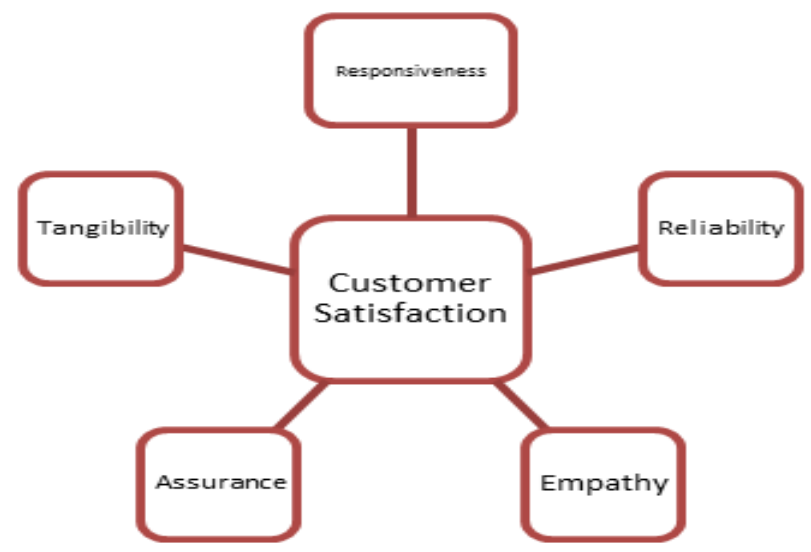

Source: Partially adapted and modified from Kant and Jaiswal [6].

In Figure 1, the conceptual model shows that customer satisfaction is affected by the service quality metrics of tangibility, reliability, responsiveness, assurance and empathy. The model explicates a relationship between each service quality dimension and customer satisfaction. The link between each of the five service quality metric may resonate with customer satisfaction.

\section{Materials and Methods}

As previously indicated, this study investigated customer satisfaction in the Tonata sub region of 
Botswana. Thus, adopting the methodological practices of Chodzaza and Gombachika [28]; Paul et al [5]; Kant and Jaiswal [6] and Hui and Zheng [7], a self-administered questionnaire was used to collect data from school managers comprising heads of schools, deputy heads of schools and heads of departments in each of the twenty-seven (27) schools in the Tonota Sub Region as they represent key informants in decision making. In each school, there were three heads of departments, one head of school, and one deputy school head. Therefore, in total, there were twenty-seven (27) heads of schools, twenty-seven (27) deputy heads of schools and eighty-one (81) heads of departments. Basically, one hundred and thirty-five (135) respondents participated in this study.

However, out of the 135 administered questionnaires, only 101 were returned giving a response rate of $74.8 \%$. Of the 101 questionnaires, two were unusable hence 99 questionnaires were finally used. This gave a $98.02 \%$ accuracy in completing the questionnaire. Since sampling frame is known, probability sampling technique using stratified random sampling technique was conducted.

A descriptive statistical analysis was applied while scale items were used to assess the underlying constructs of service quality and customer satisfaction. The items were evaluated for reliability using Cronbach's alpha.

\subsection{Questionnaire description}

The first part of the survey instrument consisted of demographic questions which enabled the collection of data about the respondents' background such as age, academic level, position at work, length of service and how long the person had occupied the current post.

The second part of the questionnaire consisted of 22 items that evaluated the respondents' rating of service offered by the Sub Region's Education Office on five sub constructs of SERVQUAL distributed as follows: tangibility (four items), reliability (five items), responsiveness (four items), assurance (five items) and empathy (four items) (1988); Kant and Jaiswal [6]; Paul et al. [5]. All the items were measured on a Five-point Likert scale (strongly disagree $=1$, disagree $=2$, can't say $=$ 3 , agree $=4$, strongly agree $=5$ ).

The third part of the questionnaire comprised three items which measured respondents' level of satisfaction towards the service offered by the public education office. Also, three items measured factors hindering customer satisfaction. All the items were measured on a Five-point Likert scale (strongly disagree-1, disagree- 2 , can't say 3 , agree -4 , strongly agree -5 ).

Table 2: Constructs and items

\section{Tangibility (TGB)}

$\mathrm{X}_{1}$ Tonota Sub Region Office information banners and boards are visually appealing

$\mathrm{X}_{2}$ Employees are well dressed and appear neat

$\mathrm{X}_{3}$ Latest equipment is available in Tonota Sub Region Office

$\mathrm{X}_{4}$ Tonota Sub Region Office has clean, attractive and convenient physical facilities

\section{Responsiveness (RSP)}

$\mathrm{X}_{5}$ Employees give prompt service to customers

$\mathrm{X}_{6} \quad$ Employees are always willing to help customers

$\mathrm{X}_{7}$ Tonota Sub Region Office has an effective complaint handling procedure

$\mathrm{X}_{8} \quad$ Employees are well trained for delivering the services and solving customers queries.

\section{Empathy (EMP)}

$\mathrm{X}_{9} \quad$ Tonota Sub Region Office gives customers individual attention

$\mathrm{X}_{10} \quad$ Tonota Sub Region Office employees understand specific needs of customers

$\mathrm{X}_{11}$ Employees at Tonota Sub Region Office give customers feedback on time

$\mathrm{X}_{12}$ Tonota Sub Region Office have their customers interest at heart

\section{Assurance (ASR)}

$\mathrm{X}_{13}$ Tonota Sub Region Office believes in fast delivery of services

$\mathrm{X}_{14} \quad$ Reports submitted to Tonota Sub Region Office are safely handled

$\mathrm{X}_{15}$ I am sure that Tonota Sub Region Office keeps my confidential details safe

$\mathrm{X}_{16}$ I feel safe to email or fax information to Tonota Sub Region Office

Reliability (RLB)

$\mathrm{X}_{17}$ Tonota Sub Region Office delivers services within the promised time limit

$\mathrm{X}_{18}$ Tonota Sub Region Office is sincere in solving customers problems

$\mathrm{X}_{19}$ Tonota Sub Region Office keeps records/information accurately

$\mathrm{X}_{20}$ Tonota Sub Region Office provides accurate services as promised

$\mathrm{X}_{21}$ Tonota Sub Region Office services are consistent and dependable

\section{Customer Satisfaction (CS)}

$\mathrm{X}_{22}$ Tonota Sub Region Office is a good service provider

$\mathrm{X}_{23}$ Tonota Sub Region Office fulfils my expectations while offering quality services

$\mathrm{X}_{24}$ Overall, I am satisfied with Tonota Sub Region 
Office service delivery

Source: Adapted from Kant \& Jaiswal (2017);

Parasuraman et al (1988)

\subsection{Ethical consideration}

Prior to administering the questionnaire, permission was sought from the Tonota Sub Region Office through a letter. Permission was granted on conditions of anonymity and confidentiality of participants. Basically, the respondents were informed that their identities would not be disclosed, and primarily their particulars would remain confidential especially considering the sensitive nature of the study. The Tonota Sub Region Office was also assured that the data would only be used for academic purposes.

\section{Results}

\subsection{Reliability and validity}

The psychometric properties for the scale items for TGB, RSP, EMP, ASR, RLB and CS were tested to establish the reliability and validity of the sub constructs in this empirical study. The Cronbach alpha for TGB, RSP, EMP, ASR, RLB and CS are $0.571 ; 0.942 ; 0.956 ; 0.909 ; 0.912$, and 0.500 respectively. The factor metrics range for TGB, RSP, EMP, ASR, RLB and CS are: 0.777- 0.994; $0.820-0.903 ; 0.749-0.932 ; 0.501-0.975 ; 0.569$ 0.874 and $0.701-0.810$ respectively. The AVE for TGB, RSP, EMP, ASR, RLB and CS are 0.624; $0.867 ; 0.862 ; 0.765 ; 0.671$ and 0.542 respectively. The KMO, AVE and factor metrics lend credence to the robustness of the factor structure in this empirical study, while the psychometric nomenclature meets the minimum threshold as established in extant literature, and these are highlighted in Table 3.

Table 3: Psychometric nomenclature of constructs measurement

\begin{tabular}{|l|l|l|l|}
\hline Construct & $\begin{array}{l}\text { Cronbach } \\
\text { Alpha }\end{array}$ & KMO & AVE \\
\hline TGB & 0.571 & 0.513 & 0.624 \\
\hline RSP & 0.942 & 0.522 & 0.867 \\
\hline EMP & 0.956 & 0.614 & 0.862 \\
\hline ASR & 0.909 & 0.623 & 0.765 \\
\hline RLB & 0.912 & 0.610 & 0.671 \\
\hline CS & 0.500 & 0.510 & 0.542 \\
\hline
\end{tabular}

Source: Researchers' construct

\subsection{Demographic profile of respondents}

The demographic characteristics of the respondents in this study include gender, age, education, length of service and number of years in the current senior management position. The senior management positions were identified as head of school, deputy head of school, and head of department.

Out of a total of 99 respondents, nearly a quarter $(24.2 \%)$ were males and three quarter, $(75.8 \%)$ were females. Over half $(58 \%)$ of the respondents had Diplomas and 40\% had Bachelors' degrees, while $1 \%$ had a Masters' degree. Nearly three in ten of the males $(27.6 \%)$ had a Diploma compared to seven in ten $(72.4 \%)$ females. On the other hand, just below a fifth $(17.5 \%)$ of the males had a Bachelor's degree compared to over four fifth $(82.5 \%)$ females.

Overall, a third (30.3\%) of the respondents were aged between $40-49$ years, while over two thirds $(68.6 \%)$ were aged 50 years and above. The majority $(76.8 \%)$ of the respondents were heads of departments; $15.2 \%$ were heads of schools while deputy heads of schools comprised $8 \%$ of the population. $21.2 \%$ had spent $16-20$ years in the service; $19.2 \%$ spent $21-25 ; 34.3 \%$ spent $26-30$ years and only $7.1 \%$ had spent between $36-40$ years.

\section{Discussion}

As shown in Table 4, TGB is significantly and positively associated with CS $(r=0.650, \mathrm{p}<0.01)$. Kant and Jaiswal [6] conducted different studies that found that politeness, personalized attention and empathy of the employees towards customers had a positive impact on their satisfaction in the Indian public and private sector banks. Furthermore, EMP is significantly and positively associated with CS $(\mathrm{r}=0.407, \mathrm{p}<0.01)$, while ASR $(\mathrm{r}=0.270, \mathrm{p}<0.05)$, RLB $(0.759, p<0.01)$ is significantly and positively associated with CS. However, RSP is not significantly associated with CS ( $\mathrm{r}=0.192)$. Based on the empirical findings in a study by Kant and Jaiswal [6] assurance was identified as a significant determinant of customer satisfaction in public sector banks in India. Similarly, Kaura [46], in a study on the banking sector in India, noted that assurance positively influenced customer satisfaction. We can confirm that our finding lends credence to Hamzah, Lee and Moghavvemi [33], in which they posit that the four key dimensions of SERVQUAL: tangibles, empathy, reliability and security set the premise for customers perceived overall SERVQUAL. They further noted that clear understanding of specific context of service quality metrics in relation to customer satisfaction is essential because customers have unique set of expectations based on the variability of services. 
Table 4: Nomological web between Tangibility, Responsiveness, Empathy, Assurance, Reliability and Customer Satisfaction in the Tonota Sub District (Correlation Matrix)

\section{Correlations}

\begin{tabular}{|c|c|c|c|c|c|c|c|}
\hline \multicolumn{8}{|c|}{ correrations } \\
\hline & & $\begin{array}{l}\text { Custo } \\
\text { mer } \\
\text { Satisf } \\
\text { action }\end{array}$ & $\begin{array}{l}\text { Tangi } \\
\text { bility }\end{array}$ & $\begin{array}{l}\text { i Respons } \\
\text { iveness }\end{array}$ & $\begin{array}{l}\text { Emp } \\
\text { athy }\end{array}$ & $\begin{array}{l}\text { Assu } \\
\text { rance }\end{array}$ & $\begin{array}{l}\text { Relia } \\
\text { bility }\end{array}$ \\
\hline \multirow[t]{3}{*}{$\begin{array}{l}\text { Custom } \\
\text { er } \\
\text { Satisfac } \\
\text { tion }\end{array}$} & $\begin{array}{l}\text { Pears } \\
\text { on } \\
\text { Corre } \\
\text { lation }\end{array}$ & 1 & $.650^{* * *}$ & $* 192$ & $\begin{array}{l}407 \\
* *\end{array}$ & $.270^{*}$ & $.759^{*}$ \\
\hline & $\begin{array}{l}\text { Sig. } \\
(2- \\
\text { tailed } \\
\end{array}$ & & .000 & .073 & .000 & .011 & .000 \\
\hline & $\mathrm{N}$ & 88 & 88 & 88 & 88 & 88 & 88 \\
\hline \multirow[t]{3}{*}{$\begin{array}{l}\text { Tangibi } \\
\text { ity }\end{array}$} & $\begin{array}{l}\text { Pears } \\
\text { on } \\
\text { Corre } \\
\text { lation } \\
\end{array}$ & $.650^{* *}$ & 1 & $.349^{* *}$ & $\begin{array}{l}.525 \\
* *\end{array}$ & $.474^{*}$ & $.674^{*}$ \\
\hline & $\begin{array}{l}\text { Sig. } \\
(2- \\
\text { tailed } \\
\end{array}$ & .000 & & .001 & .000 & .000 & .000 \\
\hline & $\mathrm{N}$ & 88 & 88 & 88 & 88 & 88 & 88 \\
\hline \multirow[t]{3}{*}{$\begin{array}{l}\text { Respons } \\
\text { iveness }\end{array}$} & $\begin{array}{l}\text { Pears } \\
\text { on } \\
\text { Corre } \\
\text { lation }\end{array}$ & .192 & $.349^{* *}$ & *1 1 & \begin{tabular}{|l|} 
\\
\end{tabular} & $285^{*}$ & .059 \\
\hline & $\begin{array}{l}\text { Sig. } \\
(2- \\
\text { tailed }\end{array}$ & .073 & .001 & & .027 & .007 & .583 \\
\hline & $\mathrm{N}$ & 88 & 88 & 88 & 88 & 88 & 88 \\
\hline \multirow[t]{3}{*}{$\begin{array}{l}\text { Empath } \\
\text { y }\end{array}$} & $\begin{array}{l}\text { Pears } \\
\text { on } \\
\text { Corre } \\
\text { lation } \\
\end{array}$ & $.407^{* *}$ & $.525^{* *}$ & $-.235^{*}$ & 1 & $.989^{*}$ & ${ }_{*} .885^{*}$ \\
\hline & $\begin{array}{l}\text { Sig. } \\
(2- \\
\text { tailed }\end{array}$ & .000 & .000 & .027 & & .000 & .000 \\
\hline & $\mathrm{N}$ & 88 & 88 & 88 & 88 & 88 & 88 \\
\hline \multirow[t]{3}{*}{$\begin{array}{l}\text { Assuran } \\
\text { ce }\end{array}$} & $\begin{array}{l}\text { Pears } \\
\text { on } \\
\text { Corre } \\
\text { lation } \\
\end{array}$ & $.270^{*}$ & $.474^{* *}$ & ${ }^{*}-.285^{* *}$ & .989 & 1 & $.807^{*}$ \\
\hline & $\begin{array}{l}\text { Sig. } \\
(2- \\
\text { tailed } \\
\end{array}$ & .011 & .000 & .007 & .000 & & .000 \\
\hline & $\mathrm{N}$ & 88 & 88 & 88 & 88 & 88 & 88 \\
\hline
\end{tabular}

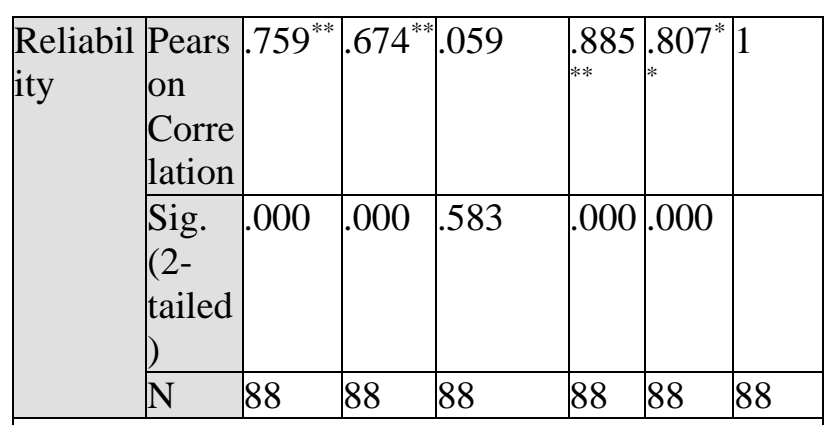

**. Correlation is significant at the 0.01 level (2tailed).

*. Correlation is significant at the 0.05 level (2tailed).

Source: Researchers' construct

The nexus of relationship between tangibility, responsiveness, empathy, assurance, reliability and customer satisfaction as shown in Table 4 indicate that TGB $(\beta=0.300, \mathrm{t}=6.18) ; \quad \mathrm{RSP} \quad(\beta=0.373, \mathrm{t}$ $=8.59)$; ASR $(\beta=1.276, \mathrm{t}=18.91) ; \operatorname{RLB}(\beta=1.606$, $\mathrm{t}=23.07)$. However, EMP is not significantly related to $\mathrm{CS}$ in the Tonota sub district. Based on the aforementioned, Hypotheses, H1, H2, H4 and H5 are supported in this empirical study, while Hypothesis H3 is not supported. Similarly, Frimpong and Wilson [47], in a study of the influence of satisfaction dimensions on service performance in Ghana, established that all the dimensions predicted customer satisfaction.

Table 5: Nexus of relationship between Tangibility, Responsiveness, Empathy, Assurance, Reliability and Customer Satisfaction in Tonota Sub District

\section{Coefficients}

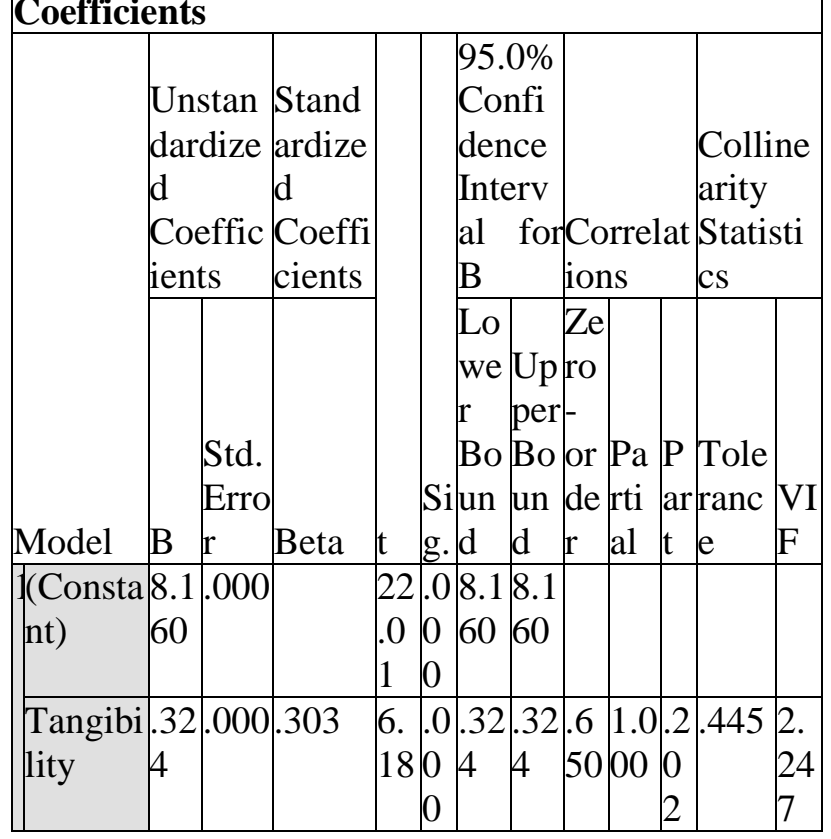




\begin{tabular}{|c|c|c|c|c|c|c|c|c|c|}
\hline $\begin{array}{l}\text { Respon } \\
\text { sivenes } \\
\text { s }\end{array}$ & $\begin{array}{l}19 \\
3\end{array}$ & .000 . & .373 & \begin{tabular}{l|l|}
8. & 0 \\
59 & 0 \\
& 0 \\
\end{tabular} & $\begin{array}{l}.19 \\
3\end{array}$ & $\begin{array}{l}.19 \\
3\end{array}$ & $\begin{array}{l}.1 \\
92 \\
\end{array}$ & \begin{tabular}{|l|}
1.0 \\
00
\end{tabular} & \begin{tabular}{|l|l|}
2.568 \\
\\
1
\end{tabular} \\
\hline $\begin{array}{l}\text { Assura } \\
\text { ace }\end{array}$ & $\begin{array}{l}.55 \\
4\end{array}$ & .000 & 1.276 & \begin{tabular}{c|c|}
18 & 0 \\
9 & 0 \\
1 & 0 \\
\end{tabular} & $\begin{array}{l}.55 \\
4\end{array}$ & $\begin{array}{l}.55 \\
4\end{array}$ & $\begin{array}{l}2 \\
70\end{array}$ & & \begin{tabular}{l|l}
6.235 \\
\\
\end{tabular} \\
\hline $\begin{array}{l}\text { Reliabil } \\
\text { ty }\end{array}$ & $\begin{array}{l}1.59 \\
0\end{array}$ & |.000 & 1.606 & \begin{tabular}{|c|c|}
23 & 0 \\
.0 & 0 \\
7 & \\
\end{tabular} & $\begin{array}{l}59 \\
0\end{array}$ & $\begin{array}{l}.59 \\
0\end{array}$ & & $\begin{array}{l}1.0 \\
00\end{array}$ & \\
\hline
\end{tabular}

a. Dependent Variable: Customer satisfaction

Source: Researchers' construct

Table 6: Measures for goodness of fit (measurement model)

\begin{tabular}{|l|l|l|l|l|l|l|l|l|l|}
\hline CMIN & DF & P & CMIN/DF & NFI & RFI & IFI & TLI & CFI & RMSEA \\
\hline 368.14 & 129 & 0.00 & 2.85 & 0.94 & 0.91 & 0.92 & 0.90 & 0.91 & 0.061 \\
\hline
\end{tabular}

A confirmatory factor analysis (CFA) was performed on the 24 items with respect to the parsimonious model of service quality metrics and customer satisfaction. Table 6 explicates the results for the measurement model and it can be confirmed that all goodness of fit measures is within the threshold as postulated by Hair, Black, Babin and Anderson [51]. The normed chi square ( $\left.X^{2} / \mathrm{df}\right), \mathrm{NFI}$, RFI, IFI, TLI and CFI are all above the threshold of 0.9 and the RMSEA is below the value of 0.08 .

\subsection{Convergent validity, discriminant validity and composite trait reliability}

As shown in Table 7, it is evident that the AVEs for all the 6 constructs exceed 0.5 and range between 0.542 and 0.86 , thus confirming convergent validity. The divergent validity was also established as shown in Table 7 in which the inter item correlations which range between 0.289 and 0.536 are less than the lowest variance extracted (54.2\%). In addition, the composite trait reliability is between 0.500 to 0.942 . Composite trait reliability could therefore be confirmed in this empirical study.

Table 7: Average variance extracted, squared interconstruct correlations and composite trait reliability.

\begin{tabular}{|l|l|l|l|l|l|l|}
\hline $\begin{array}{l}\text { Variabl } \\
\text { e }\end{array}$ & TGB & RSP & EMP & ASR & RLB & CS \\
\hline TGB & $\begin{array}{l}\mathbf{0 . 6 2 4} \\
*\end{array}$ & & & & & \\
\hline RSP & 0.536 & $\begin{array}{l}\mathbf{0 . 8 6 7} \\
*\end{array}$ & & & & \\
\hline EMP & 0.347 & 0.473 & $\begin{array}{l}\mathbf{0 . 8 6 2} \\
*\end{array}$ & & & \\
\hline ASR & 0.424 & 0.381 & 0.415 & $\begin{array}{l}\mathbf{0 . 7 6 5} \\
*\end{array}$ & & \\
\hline RLB & 0.370 & 0.297 & 0.325 & 0.386 & $\begin{array}{l}\mathbf{0 . 6 7 1} \\
*\end{array}$ & \\
\hline
\end{tabular}

\begin{tabular}{|l|l|l|l|l|l|l|}
\hline CS & 0.289 & 0.321 & 0.296 & 0.292 & 0.474 & $\begin{array}{l}\mathbf{0 . 5 4 2} \\
*\end{array}$ \\
\hline $\begin{array}{l}\text { Composite } \\
\text { Trat } \\
\text { Reliability }\end{array}$ & 0.571 & 0.942 & 0.956 & 0.909 & 0.912 & 0.500 \\
\hline & AVE reflected diagonally and squared \\
correlations below AVE.
\end{tabular}

With respect to structured model assessment in Table 8, the NFI, RFI, IFI, TLI and CFI are all within the 0.90 threshold and RMSEA is below the value of 0.08 which indicates the goodness of fit as postulated in extant literature by Hair, et al [51].

Table 8: Measures for goodness of fit (Structured model)

\begin{tabular}{|l|l|l|l|l|l|l|l|l|l|}
\hline CMIN & DF & P & CMIN/DF & NFI & RFI & IFI & TLI & CFI & RMSEA \\
\hline 426.12 & 124 & 0.00 & 3.44 & 0.94 & 0.89 & 0.92 & 0.90 & 0.97 & 0.05 \\
\hline
\end{tabular}

Table 9: Summary of Findings

\begin{tabular}{|l|l|l|}
\hline $\mathrm{H} 1$ & TGB/CS & Supported \\
\hline $\mathrm{H} 2 \mathrm{a}$ & RSP/CS & Supported \\
\hline $\mathrm{H} 2 \mathrm{~b}$ & EMP/CS & Rejected \\
\hline $\mathrm{H} 2 \mathrm{c}$ & ASR/CS & Supported \\
\hline $\mathrm{H} 2 \mathrm{~d}$ & RLB/CS & Supported \\
\hline
\end{tabular}

Source: Researchers' construct

\section{Implications of our findings}

It is common knowledge that satisfying customers private or public - can be a challenging task. The public sector gets more criticism anyhow. The spate of service delivery protests in Southern Africa for instance is testament to the degree of desperation and unhappiness that citizens experience with respect to service delivery rating of government. Therefore, understanding customer satisfaction in the public service is important for managers to devise initiatives that meet customers' needs so as to improve public trust on government programs. This could kindle some sort of impetus on employees to support public service delivery initiatives. Even though customer satisfaction is increasingly used to measure the quality of provision of public sector goods and services, this study reinforces the utility of SERVQUAL dimensions in gauging the nature and extent of service quality in the public sector generally and in Botswana specifically.

While the results show that respondents ranked tangibility higher than empathy, assurance, and responsiveness respectively in terms of contributing towards customer satisfaction, the results also identified poor information management, poor ICT equipment, poor handling of customers' grievances, and unwillingness to go an extra mile to help customers as limiting the ability of government to sufficiently deliver required 
services to citizens. In fact, some of the complaints linked failure to provide services within promised time limit and poor customer feedback as key to public service customer satisfaction. After all, public service is the system for providing government programs and projects to meet citizens' welfare using government organizations tasked to deliver goods and services to meet citizens or customers' needs based on established norms.

Significant implications of this study's findings beyond adding to the discussions on customer service quality and customer satisfaction include the identification of the need for training of employees on managing customer complaints, record management and increasing service reliability amongst others to improve service quality. Added to this is the call to use this study as a guide to formulate customer satisfaction strategies and policies aligned to service standards to drive service quality delivery. Essentially, as we have found in this study, the SERVQUAL model continues to revel in its capacity to help services managers improve performance in a number of areas as has been suggested by the likes of Alzaydi et al, [37] and Wisniewki [40]. This, as we have found in this study, can provide service managers with diagnostic support to drive continuous improvements required to meet customer needs. The gap scores as illustrated in our study can assist service managers in assessing current service quality as well as quantify gaps and taking action.

The dimensions of service quality provide the immense opportunity to assess the extent to which customers are satisfied or dissatisfied with the goal of instituting appropriate interventions. The obvious implication of this finding is the need for continuous training and development of managers of public service offices and programs in the art of understanding and using service quality dimensions to assess how sufficiently they are supporting and satisfying their customers.

There are equally some scholarly implications. First is our acknowledgment of the limitation of this study, which offers a new vista for research opportunities in the subject matter and in Botswana. The first limitation is our use of the quantitative method in collecting data. The quantitative approach to collecting data can be limiting in the sense that it does not allow for opportunities for intimate expression of feelings and experience. The utility of the Likert scale only allows for responses to prepared questions hence participants are not able to properly disclose or express their real life experiences. In this regard, future research on the subject within Botswana may best deploy a mixed methods approach to derive rather generalizable conclusions.

Speaking of generalizable conclusions, we are wary of another shortcoming of this study and that is that our study only considered basic school management teams comprising school heads, deputy school heads and heads of departments and managers within a sub-regional education office in Tonota, Botswana. While there is a likelihood that the experience of the management teams in Tonota may be reflective of the experiences of other management teams in other regions, we are hesitant to suggest that our findings may be generalized. In addition, the hypotheses have only been tested in the public service of Botswana which limits the external validity of the results. Based on the foregoing, one should be cautious in generalizing the findings across other industry, sector or countries. Equally of concern is the number of participants in this study. Perhaps, a larger sample could realize a different result. Therefore, a future study may consider other regions using the mixed methods approach, a larger sample and perhaps an extensive and rigorous statistical method. Furthermore, other dimensions of SERVQUAL such as trust, commitment, adaptation, communication, cooperation as suggested by Shin, Thai and Yuen [22] could be proposed in order to explicate the nomological web of psychometric competence of the factor structure. Future research could also examine numerous industries to set the premise for generalizations and representativeness. Service quality metrics for the private and public sector could also be compared most especially as Botswana seeks to transform its economy from mineral-led to knowledge based economy.

\section{Conclusions}

We set out to examine the extent to which dimensions of service quality influence customer satisfaction in the Tonota Sub Region using a questionnaire, which facilitated the collection of data from 135 respondents from 27 basic education facilities and we found that service quality dimensions of tangibility, empathy, assurance and responsiveness impact customer satisfaction positively. But, these findings are not enough. We declare this on the basis of the continued dissatisfaction of customers regarding public sector service delivery standards. Despite the Botswana's governments interventions namely the National Productivity Program, Work Improvement Teams Strategy (WITS), decentralization and a Performance Management System (PMS) to address concerns over public service delivery, this study 
insists that the government of Botswana and several others will continue to experience service delivery displeasures unless a proper establishment and uptake of training programs by the government and its employees; the establishment of reward and incentive programs for excellent performance as well as a continuous review of service quality standard programs take place.

\section{References:}

[1] Jenkins, W. (2009). Sustainability theory Berkshire encyclopedia of sustainability: the spirit of sustainability, 380-384.

[2] Iwu, CG. (2018) The sustainability of small or medium enterprises growth in emerging markets. In Proceedings of the International Conference on Business and Management Dynamics (ICBMD), 213-221.

[3] Pizam, A., Shapoval, V; and Ellis, T. (2016) Customer satisfaction and its measurement in hospitality enterprises: a revisit and update, International Journal of Contemporary Hospitality Management, 28(1) 2-35, https://doi.org/10.1108/IJCHM-04-2015-0167.

[4] Makanyeza, C and Chikazhe, L. (2017) Mediators of the relationship between service quality and customer loyalty: Evidence from the banking sector in Zimbabwe, International Journal of Bank Marketing, 35(3) 540-556, https://doi.org/10.1108/IJBM-11-2016-0164.

[5] Paul, J., Mittal, A. and Srivastav, G. (2016) Impact of service quality on customer satisfaction in private and public sector banks, International Journal of Bank Marketing, 34(5) 606-622, https://doi.org/10.1108/IJBM-03-2015-0030.

Accessed 28/02/2018.

[6] Kant, R and Jaiswal, D. (2017) The impact of perceived service quality dimensions on customer satisfaction: An empirical study on public sector banks in India, International Journal of Bank Marketing, $35 \quad$ (3) 411-430, https://doi.org/10.1108/IJBM-04-2016-0051.

[7] Hui, E. C. M., and Zheng, X. (2010) Measuring customer satisfaction of FM service in housing sector: A structural equation model approach, Facilities, 28(5/6) 306-320, https://doi.org/10.1108/02632771011031538.
[8] Kealesitse, B., O’Mahony, B., Lloyd-Walker, B., and Jay-Polonsky, M. (2013) Developing customerfocused public sector reward schemes: Evidence from the Botswana government's performance-based reward system (PBRS). International Journal of Public Sector Management, 26 (1), 33-55 https://doi.org/10.1108/09513551311293426.

[9] Nkwe, N. E-Government: Challenges and Opportunities in Botswana, (2012) International Journal of Humanities and Social Science, 2 (17).

[10] Ramakele, M and Koloi-Keaikitse, S. (2016) Analysis of performance management system as an appraisal tool used in Botswana colleges of education. Mosenodi Journal,19(1) 86- 105.

[11] Alam-Siddiquee, N, (2008) Service delivery innovations and governance: The Malaysian experience, Transforming Government: People, Process and Policy, 2(3) 2 194-213, https://doi.org/10.1108/17506160810902194.

[12] Ali, F., Dey, B.L., and Filieri, R. (2015) An assessment of service quality and resulting customer satisfaction in Pakistan International Airlines: Findings from foreigners and overseas Pakistani customers, International Journal of Quality \& Reliability Management, 32(5) 486-502, https://doi.org/10.1108/IJQRM-07-2013-0110.

[13] $\mathrm{Wu}, \mathrm{H} . \mathrm{C}$. (2014) The effects of customer satisfaction, perceived value, corporate image and service quality on behavioural intentions in gaming establishments, Asia Pacific Journal of Marketing and Logistics, 26(4),540-565. https://doi.org/10.1108/APJML-03-2014-0049.

Accessed on 28/04/2018.

14] National Human Resource Development Strategy (NHRDS:2009-2022): Realising Our Potentials: Republic of Botswana: Ministry of Education and Skills Development.

[15] World Economic Forum, (2019). Global Competitiveness Report.

[16] Hope, K.P.S. (1995) Managing the public sector in Botswana: Some emerging constraints and the administrative reform responses, International Journal of Public Sector Management, 8(6), 51-62 https://doi.org/10.1108/09513559510100024.

[17] Matambo, O.K. (2015) Budget Speech, Ministry of Finance and Development Planning, 
Republic of Botswana, Government Printers, Gaborone.

[18] Botlhale, E, (2017), Enhancing public project implementation in Botswana during the NDP 11 period. Africa's public service delivery and performance review, 5(1) 163. https://doi.org/10.4102/apsdpr.v5i1.163

[19] NDP 11. National Development Plan 11, April 2017 - March 2023. (2016); 1. Government Printers. Gaborone.

[20] Jaiyeoba, O.O., Chimbise, T.T., Makanyeza, C., and Iwu, C.G (2018a). Distribution efficiency of e-services in the health insurance sector: the case of Botswana, Journal of Distribution Science, 16(5) 515.

[21] Yuen, K., and Thai, V., (2017) The influence of Supply chain integration on operational performance: a comparison between product and service supply chains., International Journal of Logistics Management, 28(2), 444-463.

[22] Shin, T.V., and Yuen, K.F. (2018) The impact of supply chain performance in the maritime logistics industry in light of firm characteristics, The International Journal of Logistics Management, 29(3) 1077-1097.

[23] Daily News (2018). In our quest to improve service delivery within public service, we pledge the following to our customers. Botswana Daily News, 071, 13

[24] Oludele, A. A., Emilie, C. K., and Mandisa, P. M. (2012) An analysis of citizen satisfaction with public service delivery in the Sedibeng district municipality of South Africa, International Journal of Social Economics, 39(3) 182-199, https://doi.org/10.1108/03068291211199350.

[25] Izogo, E.E.,and Ogba, I.E.(2015) Service quality customer satisfaction and loyalty in automobile repair services sector, International Journal of Quality \& Reliability Management, 32(3) 250-269, https://doi.org/10.1108/IJQRM-052013-0075.

[26] Jain, P. (2005) Strategic human resource development in the public libraries in Botswana, Library Management, 26 (6/7) 2005; 336-350, https://doi.org/10.1108/01435120410609752.
[27] Bellingkrodt, S., and Wallenburg, C. M. (2015) The role of customer relations for innovativeness and customer satisfaction: a comparison of service industries, The International Journal of Logistics Management, 26(2), 254-274, https://doi.org/10.1108/IJLM-06-2012-0038.

[28] Chodzaza, G. E., and Gombachika, H. S. H. (2013) Service quality, customer satisfaction and loyalty among industrial customers of a public electricity utility in Malawi, International Journal of Energy Sector Management, 7(2) 269-282, https://doi.org/10.1108/IJESM-02-2013-0003.

[29] Jaiyeoba, O.O., Chimbise, T.T., RobertsLombard, M. (2018) E-service usage and satisfaction in Botswana, African Journal of Economic and Management Studies, 9(1), 1, 2-13, https://doi.org/10.1108/AJEMS-03-2017-0061.

[30] Fishbein,M., and Ajzen,I., (1975) Belief, Attitude, Intention and Behaviour: An introduction to Theory and Research, ARRB Group. Victoria.

[31] Meskaran, F., Isamil, Z., and Shanmugam, B., (2015) Online purchase intention: effects of trust and security perception, Australian Journal of Basic and Applied Sciences, 17(6), 307-315.

[32] Tsoukatos, E., and Mastrojianni, E, (2010) Key determinants of service quality in retail banking, Euromed Journal of Business, 5(1) 85-100.

[33] Hamzah, Z.L, Lee, S.P., and Moghavvemi, S (2016), Elucidating perceived overall service quality in retail banking, International Journal of Bank Marketing, 35(5), 781-804.

[34] Lee, S.P., and Moghavvemi, S, (2015) The dimension of service quality and its impact on customer satisfaction, trust and Loyalty: Case of Malaysian Banks, Asian Journal of Business and Accounting, 8(2)., 91-121.

[35] Daniels, K.T.,and Nicholas, R. (2013) Determinants of customer loyalty in Kenya: does corporate image play a moderating role? The TQM Journal, 25(5) 473-491, https://doi.org/10.1108/TQM-11-2012-0102.

[36] Jamali, D. (2007) A study of customer satisfaction in the context of a public private partnership, International Journal of Quality \& Reliability Management, 24(4) 370-385, https://doi.org/10.1108/02656710710740545. 
[37] Alzaydi, Z.M., Ali-Hajla, A., Nguyen, B., and Jayawardhena, C. (2018) A review of service quality and service delivery: Towards a customer co-production and customer-integration approach, Business Process Management Journal, 24(1) 295328, https://doi.org/10.1108/BPMJ-09-2016-0185.

[39] Parasuraman, A., Zeithaml, V.A. and Berry, L.L. (1988) Servqual: A multiple-item scale for measuring consumer perceptions of service quality. Journal of Retailing, 1988, 64(1), 12.

[40] Wisniewki, M. (2001) Using SERVQUAL to assess customer satisfaction with public sector services, Managing Service Quality: An International Journal, 11(6) 380-388, https://doi.org/10.1108/EUM0000000006279.

[41] Andrews, D., and Turner, S. (2017) Improving the customer experience through consistency and effective service delivery in the United Kingdom public house sector, British Food Journal, 119(3) Vol. 119 587-599, https://doi.org/10.1108/BFJ-072016-0326.

[42] Brysland, A., and Curry, A. (2001) Service improvements in public services using SERVQUAL, Managing Service Quality: An International Journal, 11(6) 389-401, https://doi.org/10.1108/09604520110410601.

[43] Thapisa, A.P.N.,and Gamini, V. (1999) Perceptions of quality service at the University of Botswana Library: what Nova says, Library Management, 20(7) , 373-383, https://doi.org/10.1108/01435129910285145.

[44] Silvestri, C., Aquilani, B. and Rugieri, A. (2017) Service quality and customer satisfaction in thermal tourism, The TQM Journal, 29(1) 55-81, https://doi.org/10.1108/TQM-06-2015-0089.

[45] Bittencourt O, Verter V, and Yalovsky M. (2018) Hospital capacity management based on the queueing theory. International Journal of Productivity and Performance Management, 67(2), 224-38. https://doi.org/10.1108/IJPPM-12-20150193.

[46] Kaura, V. (2013) Antecedents of customer satisfaction: a study of Indian public and private sector banks, International Journal of Bank Marketing, 31(3) 167-186, https://doi.org/10.1108/02652321311315285.

Accessed on 07/06/2018
[47] Frimpong, K., and Wilson, A. (2013) Relative importance of satisfaction dimensions on service performance: A developing country context, Journal of Service Management, 24(4) 401-419, https://doi.org/10.1108/JOSM-07-2012-0151.

[48] Whyte, G and Bytheway, A. (2017) The Vmodel of service quality: An African case study, European Journal of Marketing, 51(5/6) 923-945, https://doi.org/10.1108/EJM-05-2015-0270.

[49] Biscaia, A. R., Rosa, M.J., Moura, E.S.P., and Sarrico, C.S. (2017) Assessing customer satisfaction and loyalty in the retail sector, International Journal of Quality \& Reliability Management, 34(9) 15081529, https://doi.org/10.1108/IJQRM-03-20150039 .

[50] Russell, E.W and Bvuma, D. G. (2001) Alternative service delivery and public service transformation in South Africa, International Journal of Public Sector Management, 14(3) 241-265, https://doi.org/10.1108/09513550110390819.

[51] Hair, J.F., Black,W.C., Babin,B.J., Anderson, R.E.,(2014) Multivariate Data Analysis, 7th Edition., Pearson, Harlow,

\section{Creative Commons Attribution License 4.0 (Attribution 4.0 International , CC BY 4.0)}

This article is published under the terms of the Creative Commons Attribution License 4.0 https://creativecommons.org/licenses/by/4.0/deed.en US 